Jjpn. J. Hosp. Pharm.

$\left[\begin{array}{l}15(5) \quad 365-367(1989)^{k} \\ \text { ín }\end{array}\right]$

\title{
メキシレチン経口服用量と血中濃度の関係
}

\author{
上野和行, 河島修一, 上本清隆, 笺 偕子, 宮井一義 \\ 国立療養所千石荘病院薬剤科*
}

\section{The Relationship of Dose of Mexiletine with Serum Concentration}

\author{
KAZUYUKI UENO, SYUICHI KAWASHIMA, KIYOTAKA UEMOTO, \\ TOMOKO IKADA, and KAZUYOSHI MIYAI \\ Department of Pharmacy, National Sanatorium Sengokuso Hospital*
}

(Received March 13, 1989)

Keywords—dose; mexiletine; serum concentration; suitable dose

\section{はじめ.に}

メキシレチン (以下 MXと略す) は, 電気生理学的に は Vaughan Williams の分類上"), リドカインと同様に クラス Ib に分類されている抗不整脈治療薬である. MX はリドカインのように肝において初回通過効果は受けに くく Bioavailability が約 85\% であると報告されて いる2). したがって, 経口投与が可能で広く臨床で使用 されている. しかし, MXの有効治療血中湦度域が狭 く3 6), 血中湱度モニタリングの必要性がいわれている.

$\mathrm{MX}$ の体内動態に関して生物学的半減期は約 10 時間 で7 8), 体内分布容積は 5 12L/ $/ \mathrm{kg}^{2,77}$ で比較的個人差が あると報告されている. そして $\mathbf{M X}$ の維持投与量は 10 〜 14mg/kg と述べられている ${ }^{9210)}$. しかし, これらの報 告はすべて外国人によるすのであり, 日本人における報 告は少ない11 12). 今回, 当院入院中の MX释口服用患者 における服用量と血中湦度值との関係を検討したので報 告する.

\section{主方法}

\section{1. 同古期间と対㷪}

1987年 4 月から1988年12月までの間, 当院に入院し,

* 大阪府貝塚市名越1191; 1191, Nagose, Kaizukashi, Osaka, 597 Japan
MXを服用した患者を調査対象とした. 今回は特に服用 方法が 1 日 3 回毎食後すぐ服用の患者のみを対象とし た. 服用期間は全症例 1 週間以上であったので, 血中濃 度的には定常状態に達している患者であった. また， フ エニトイン13)，リファンピシン14) は MXのクリアラン スを大きくすると報告されているので, 今回の測定対象 はこれらの薬物を併用していなかった.

\section{2. 周 料}

MX，および高速液体クロマトグラフィー (HPLC)の 内部標準として用いた 4-Methylmexiletine は，日本べ ーリンガーインゲルハィム (川西市) から提供をうけ た. アセトニトリルは HPLC 用, その他の試薬類は試 薬特級品を用いた。

\section{3. 血中湌度測定}

採血時刻は全症例午前 6 時であった. したがって, 血 中濃度的には最低血中濃度 $\left(\mathrm{C}_{\min }\right)$ であると考えられ る. MX の血中濃度測定は. HPLC (島津製作所 6A シス テム, 京都) を用いて行った. 展開条件は Mastropalo ら15) の変法で, カラムは Shima-pack ODS $15 \mathrm{~cm}$, 移 動相は $0.1 \mathrm{M} \mathrm{KH}_{2} \mathrm{PO}_{4}: \mathrm{CH}_{3} \mathrm{CN}(75: 25)$, 流速 $1.5 \mathrm{ml}$ / $\min , \mathrm{UV} モ=タ ー 205 \mathrm{~nm}$, カラム温度 $40^{\circ} \mathrm{C}$ で, 内部 標準は 4-Methylmexiletine を用いた. 検体の前処理は エーテル抽出法によった（Fig.1). 


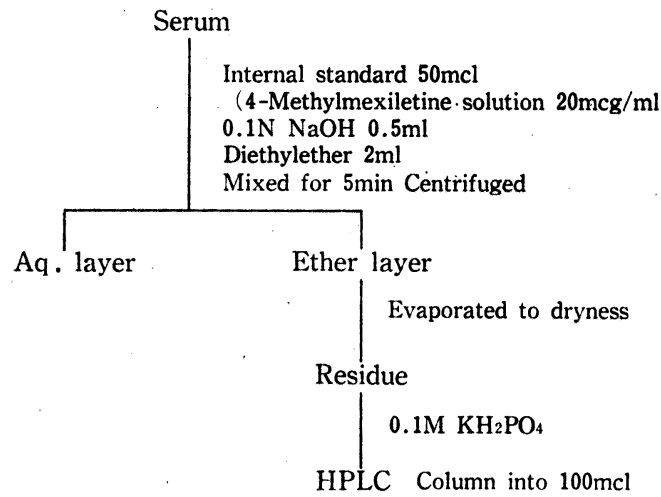

Fig. 1. Extraction Procedure for High-performance Liquid Chromatography Method

\section{䊅}

今回調査を行った対象の年令，体重をTable 1 に，ま た服用量と血中濩度值の相関をFig. 2 に示した. 女性に おける回㷌直線は $Y=0.167+0.110 X$, 男性では $Y=-$ 0.0785+0.142X であった，両者共にほぽ原点を通る直

Table 1. Age and Weight of Subject

\begin{tabular}{lccccc}
\hline & N & \multicolumn{2}{c}{ Age $(\mathrm{yr})$} & \multicolumn{2}{c}{ Weight $(\mathrm{kg})$} \\
& & Mean & $\mathrm{SD}$ & Mean & $\mathrm{SD}$ \\
\hline Female & 14 & 71.3 & 10.6 & 49.7 & 12.0 \\
Male & 14 & 63.4 & 11.5 & 52.3 & 10.6 \\
Total & 28 & 68.7 & 11.3 & 51.0 & 11.2 \\
\hline
\end{tabular}

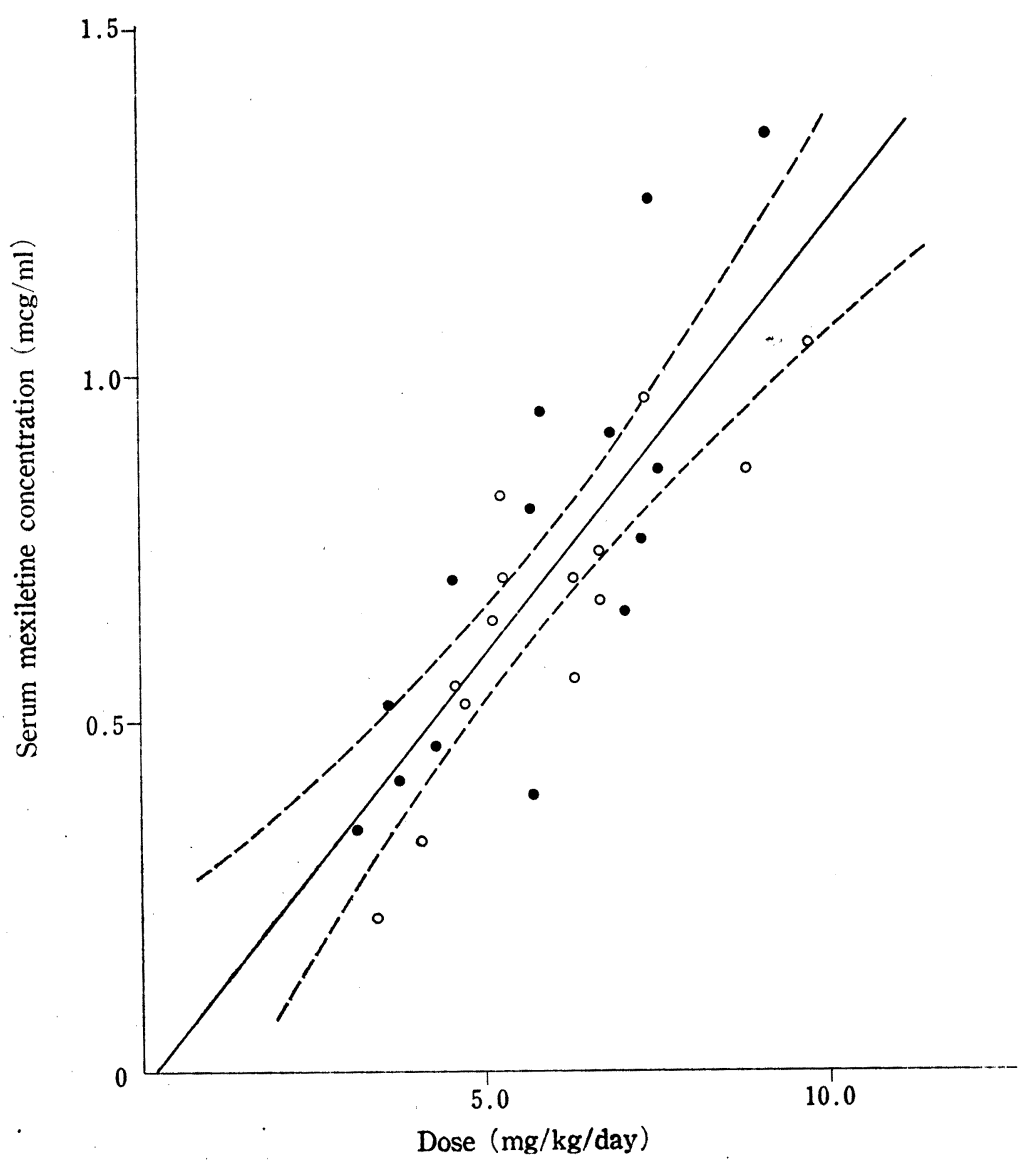

Fig. 2. The Relationship of Dose and Serum Mexiletine Concentration $\bigcirc$; Female $\mathrm{N}=14$, $\bigcirc$; Male $\mathrm{N}=14$

The regression equation determined by the least squares method is $\mathrm{Y}=-0.0244+0.125 \mathrm{X}(\mathrm{r}=0.814, \mathrm{n}=28)$ as shown with solid line. The dotted lines represent confidence limits (95 percent) for the regression line. 
線で，相関係数もそれぞれ $r_{1}=0.851 ， r_{2}=0.818$ であ った. 全症例を用いて算出した回㷌式は $\mathrm{Y}=-0.244+$ $0.125 \mathrm{X}$ で, 相関係数は $\mathrm{r}=0.814$ であった。

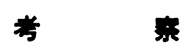

MX 服用量と血中灌度については，女性，男性，それぞ れの回㷌直線に大きな差を認めなかったので(Fig. 2)， 性差が票めて小さいと解釈される. 全例における MXの 服用量と血中浱度との相関関係は，ほぼ原点を通る直線 の関係として示される $(r=0.814)$. すなわち，MXの血 中浱度は服用量に対して正の相関を示し, 回帰式から, MX の体重あたりの至適投与量を推察することが可能で あると考えられた.

MX の有効血中㴤度域は, 外国人のデータではあるが $0.5 \sim 2.0 \mu \mathrm{g} / \mathrm{ml}$ と報告されている ${ }^{3 \sim 8)}$. 今回対象の採血 時刻は午前 6 時であったため, 血中浱度值としてはほほ $\mathrm{C}_{\min }$ と考えられる. そこで, 至適投与量を求めるにあ たり $\mathrm{C}_{\min }$ が 0.5 以上であればよいと仮定し, 回㷌值線 より求めると, その最少量 $\left(D_{\min }\right)$ は $4.2 \mathrm{mg} / \mathrm{kg}$ と算出 される.

次に, 至適投与量の最高量 $\left(\mathrm{D}_{\mathrm{max}}\right)$ を考える. 今回対 象の最終服用時刻は18時で, 採血時刻は午前 6 時であ る. MX経口時の体内動態は臨床的には 1-compartment model に従うと報告され, 外国人の最高血中瀑度到達時 間 ( $\left.T_{\max }\right)$ は約 2 時間で, 半減期が約10時間7 8)である ので, 最高血中䈨度 $\left(\mathrm{C}_{\max }\right)$ は $\mathrm{C}_{\min }$ の約 2 倍となる. したがって, $C_{\min }$ の回㷌直線と外国人における有効血 中浱度域を使えば, $D_{\max }$ は $8.2 \mathrm{mg} / \mathrm{kg}$ と算出される.

したがって, 本症例の（MXの 1 日 3 回毎食後すぐ服 用時）至適投与量は 4.2 $8.2 \mathrm{mg} / \mathrm{kg}$ となる. 外国人の 至適投与量は $10 \sim 14 \mathrm{mg} / \mathrm{kg}$ と報告されているので, 今 回の結果は外国人の約半分程度となり興味深い.

\section{引用文 跨}

1) EM. Vaughan Williams, J. Clin. Pharmacol., 24, 129-147 (1972).

2) V. Haselbarth, JE. Doevendans and M. Wolf, Clin. Pharmacol. Ther., 29, 729-736 (1981).

3) SP. Joseph and DW. Holt, Eur. J. Cardiol., 11, 115-121 (1980).

4) RL. Woosley, T. Wang and W. Stone, Am. Hear. J., 107, 1058-1065 (1984).

5) BB. Leahy and JT. Bigger, Am. Int. Med., 92, 427-429 (1980).

6) NPS. Campbell, JF. Pantridge and AAJ., Adgey $\mathrm{Br}$. Heart J., 40, 796-801 (1978).

7) LF. Prescott, A. Pottage and JA. Clements, Postgrad. Med. J., 53(Suppl. 1), 50-55(1977).

8) NPS. Campbell, JG. Kelly, AAJ. Adgey and RG. Shanks, Br. J. Pharmacol., 6, 103-108 (1978).

9) A. Pottage, Postgrad. Med. J., 53, 155-157 (1977).

10) BN. Singh, YW. Cho and HP. Kuemmerle, Int. J. Clin. Pharmacol. Toxicol., 19, 185199 (1981).

11）加藤林也, 外畑岩夫, 林 博史, 都策実紀, 棚橋 淑文, 横田充弘, 山内一信, 跻床薬理, 13, 505513 (1982).

12) K. Ohashi, A. Ebihara, T. Hashimoto, F. Hosoda, K. Kondo, and T. Oka, Arzneimittelforsch., 34 ( I ), 503-507 (1984).

13) EJ. Begg, PM. Chinwah, C.Webb, and Wade Day \& DN, Br. J. Clin. Pharmacol., 14, 219 -223 (1982).

14) PJ. Pentikainen, TH. Koivula and HA. Hiltunen, Eur. J. Clin. Pharmacol., 23, 261-266 (1982).

15) W. Mastropalo, DR. Holmes, MJ. Osborn, J. Rooke and TP. Moyer, Clin. Chem., 30, 319-322 (1984). 